\title{
The role of local government management of tourism in fostering residents' support to sustainable tourism development: evidence from a Portuguese historic town
}

\section{Isabel Vieira}

Higher Education School of Technology and Management, Polytechnic Institute of Viseu,

Lamego, Portugal

Email: ivieira@estgl.ipv.pt

\section{Ana Rodrigues*}

Department of Economics, Sociology and Management, University of Trás-os-Montes and Alto Douro,

Vila Real, Portugal

Email: anarodri@utad.pt

*Corresponding author

\section{Didiana Fernandes}

Higher Education School of Technology and Management, Polytechnic Institute of Viseu,

Lamego, Portugal

Email: dribeiro@estgl.ipv.pt

\section{Carlos Pires}

University of Trás-os-Montes and Alto Douro,

Department of Mathematics,

Vila Real, Portugal

Email: carlosandrepires@gmail.com

\begin{abstract}
This study proposes a conceptual framework that explores the correlations between economic dependence (ED), local government management of tourism (GMT), perceived tourism benefits and costs, and support for sustainable tourism development (STD). A quantitative research design was adopted. Data collection was carried out by personal survey applied to 300 residents of the small historic town of Lamego, located within the Douro Valley World Heritage Site. Structural equation modelling methods were employed to analyse the proposed model. Results suggest that GMT has a significant effect on the perceived impacts of tourism, both in the positive and in the negative. The effect of GMT in fostering residents' support to STD was also empirically supported. Additionally, it was also determined that positive perceptions of the impacts of tourism directly influence support to STD. Nevertheless, ED does not have a significant effect either on perceived
\end{abstract}


benefits, nor on perceived costs or on residents' support to STD. Likewise, perceptions of the negative impacts do not predict residents' support to STD.

Keywords: local government management of tourism; economic dependence; impacts of tourism; support to sustainable tourism development; Portugal.

Reference to this paper should be made as follows: Vieira, I., Rodrigues, A., Fernandes, D. and Pires, C. (2016) 'The role of local government management of tourism in fostering residents' support to sustainable tourism development: evidence from a Portuguese historic town', Int. J. Tourism Policy, Vol. 6, No. 2, pp.109-135.

Biographical notes: Isabel Vieira received her $\mathrm{PhD}$ in Management from the UTAD, Portugal, Master's degree in Heritage and Tourism from the University of Minho and Bachelor's degree in Tourism of the University of Algarve. She is a full researcher at the Centre for the Study of Education, Technologies and Health (CSETH) and is a collaborating researcher at (Center of Transdisciplinary Studies for Development - UTAD (CETRAD). Her areas of interest are tourism, heritage and sustainable tourism development. She regularly attends and presents papers at national and international conferences.

Ana Rodrigues received her $\mathrm{PhD}$ in Management from the UTAD, Portugal, Master's degree in Marketing from the University of Minho and Bachelor's degree in Management from the UTAD. She is a full researcher at Center of Transdisciplinary Studies for Development - UTAD (CETRAD). Her areas of interest are internal marketing, entrepreneurship, spirituality, heritage and cultural tourism, sustainable tourism development and religious tourism. In recent years, she has published in scientific journals in the marketing and tourism areas and has published articles in the proceedings at various international conferences. She is involved in several studies and research projects.

Didiana Fernandes received her PhD in Cultural Sciences from the UTAD, Portugal, Master's degree in Local and Regional Studies from the University of Oporto and degree in Tourism from the University of Aveiro. She is a full researcher at the Centre for the Study of Education, Technologies and Health (CSETH). Her areas of interest are tourism, tourism development, local and regional tourism, development of cultural tourist routes, and also travel literature and comprehension of space. She regularly attends and presents papers at national and international conferences.

Carlos Pires received his Bachelor's degree in Mathematics from the UTAD, Portugal. He is a Master's student of Applied Statistics at UTAD. He is a collaborator of the Centre for Mathematics of UTAD (CM-UTAD). As a statistician, he has participated in several studies and research projects in different fields of science. His primary research interest is the study of structured additive regression models.

This paper is a revised and expanded version of a paper entitled 'The role of government management of tourism in fostering residents support for sustainable tourism development: evidence from a Portuguese historic town' presented at ICOT2015 - From Tourism Policy into Practice: Issues and Challenges in Engaging Policy Makers and End Users, Middlesex University, London, UK, 24-27 June 2015. 


\section{Introduction}

Tourism is an activity of strategic importance in most countries' economic, social and environmental circumstances (Henriques, 2003). As with other industries, it is often seen as a tool for development, at both national and regional levels (Jackson, 2008). It is an important source of employment, income and wealth. Nevertheless, due to its rapid expansion, it also has a detrimental impact when it's not properly and sustainably managed. As a result, we have been witnessing a growing interest in sustainable tourism development, by both public and private organisations.

Sustainable tourism development (STD) requires a multidisciplinary approach, because of its ample nature, and entails the development of projects and strategies that integrate its various dimensions - economic, social, cultural and environmental (Kuvan and Akan, 2005; Pulido Fernández and Sánchez Rivero, 2009). Both cooperation from relevant stakeholders and a strong political leadership are crucial for the sustainable development of tourism (Henriques, 2003; Ruhanen and Reid, 2014). It is a continuous process that requires constant monitoring of its impact. Hence, the critical importance of an adequate planning process adjusted to local conditions, and of an efficient and continuous management of tourism activities.

On any destination, the local residents' support is vital for the sustainability of the tourism industry (Gursoy et al., 2010; Sharma and Dyer, 2012; Stylidis et al., 2014). Thus, the success of any effort of sustainable development depends on engaged support from local communities (Gursoy and Rutherford, 2004; Nunkoo and Ramkisoon, 2010). In this context, there is an increasing interest in literature on residents' support to STD (Ko and Stewart, 2002) and its antecedents. Understanding the antecedents for residents' support to STD is of crucial importance for local government, policy makers and tourism businesses.

The tourism industry influences the lives of local communities (Jurowski, 1994) for either better or worse. In tourism literature, the term 'impacts of tourism' has been increasingly gaining attention (García et al., 2015). Over the past few years, a number of studies have examined the residents' perceptions of the impacts of tourism (Brida et al., 2011; Cañizares et al., 2014; García et al., 2015; Sharma and Dyer, 2012; Stylidis et al., 2014; Vareiro and Mendes, 2015;), and still, it remains a crucial issue (Deery et al., 2012; Ko and Stewart, 2002; Mazón et al., 2009). Drawing on the 'triple bottom line approach' (Stylidis et al., 2014), several studies have outlined the impacts of tourism on the economic, socio-cultural and environmental dimensions (Brida et al., 2011; Nunkoo and Ramkisoon, 2010). In each of these dimensions, there is potential for both positive (benefits) and negative (costs) aspects (Prayag et al., 2013; Stylidis et al., 2014). Knowledge about the residents' perceptions of the impacts tourism has on their communities is of utmost importance for both the industry and the government's tourism departments and agencies (Deery et al., 2012), because this knowledge is what should lead the process of managing places and consequently, planning of tourism activities, marketing them and developing tourism products and programs (Gursoy and Rutherford, 2004). Thus, an understanding of local residents' perceptions of tourism "is considered a vital ingredient of tourism planning and management" [Sharpley, (2014), p.42].

There are not many studies that analyse residents' support to STD in historical towns (Rodrigues et al., 2014), especially in relation with economic dependence and local government management of tourism. Local authorities are pivotal in developing actions 
aimed at guaranteeing tourism becomes increasingly sustainable (Brokaj, 2014). Considering that it is locally that discussions on policies are developed and decisions about resources are taken (Brokaj, 2014), the importance of local government in stimulating actions that foster STD is widely acknowledged (Ruhanen, 2013). However, less attention has been given to the examination of the local authorities' role in addressing STD issues in tourism destination contexts (Brokaj, 2014; Ruhanen, 2013). Particularly, it is relevant to assess if an efficient local government management of tourism influences the perceived impacts of tourism and the support to STD. Additionally, it is important to analyse the role of economic dependence in shaping the residents' perception of the impacts and their support to STD. In other words, to what extent would the residents' dependence on the tourism industry (i.e., income and employment) predict the positive or negative impacts of tourism and the support that local communities give to STD initiatives?

In this paper, we propose a conceptual model that explores the antecedents for residents' support to STD of a historical town (Town of Lamego), in northern Portugal. The main purpose is to, based on the residents' perceptions, analyse the relationships between the following variables: economic dependence, local government management of tourism, perceptions of the impacts of tourism, and support to STD.

This paper is divided into five sections. After the introduction, the second section reviews the literature related to this study and presents the proposed hypotheses. The methodology used for empirical purposes is described in the third section. The fourth section presents the empirical findings, and the final section provides the study's discussion and conclusions.

\section{Literature review and proposed hypothesis}

\subsection{STD and residents' support}

The United Nations World Tourism Organization (UNWTO) defines sustainable tourism as "Tourism that takes full account of its current and future economic, social and environmental impacts, addressing the needs of visitors, the industry, the environment and host communities" [World Tourism Organization (WTO), (2005), p.12]. According to this organisation, the development of this type of tourism requires the informed participation of all stakeholders, as well as a strong political leadership to ensure wide participation and consensus. It is a continuous process that requires constant monitoring of impacts (WTO, 2005). Byrd et al. (2009) argue that, in 2004, to further describe and explain sustainable tourism, the WTO expanded its definition. The detailed description "addresses six main principles: (1) high level of tourist satisfaction, (2) make optimal use of environmental resources, (3) respect the socio-cultural authenticity of host communities, (4) provide socio-economic benefits to all stakeholders, (5) constant monitoring of impacts, and (6) informed participation of all relevant stakeholders, as well as strong political leadership" [WTO, 2004 in Byrd et al., (2009), p. 41].

The importance of STD is widely acknowledged by professionals and scholars in the tourism industry (Byrd et al., 2009). This concept has attained extensive acceptance as a desirable option of tourism development (Nicholas and Thapa, 2010). There has been a positive evolution of the concept of STD, because initially the issue of sustainability was focused only on environmental aspects having subsequently started to integrate 
economic, social and cultural factors related to power and social equity (WTO, 2005). WTO emphasises that STD guidelines and management practices are appropriate to all forms of tourism in all types of destinations, including mass tourism and the various niche tourism segments. The principles of sustainability are aspects of tourism development related to environmental, economic and socio-cultural issues, and a suitable balance between these three conditions must be established to guarantee its long-term sustainability (WTO, 2005). Regarding STD in culture and heritage contexts, Garrod and Fyall (2000) draw attention to the scarcity of studies, stating that it is surprising how little academic attention has been given to exploring the relationship between heritage tourism and sustainability, because the two concepts clearly share a common theme.

Tourism must respect the rights and wishes of local people and provide the opportunity for broad sectors of the community to contribute in decision-making, planning and tourism management. It is generally agreed that the residents' participation in local planning is essential to achieve the destination's sustainable development (Chen and Chen, 2010; Dyer et al., 2007). Accordingly, it is of vital importance that the various stakeholders involved in the process, such as local governments, politicians, heritage managers and companies, which, in most cases, lead conflicting development processes, understand the importance of this involvement and realise that the success of a sustainable development plan depends on the engaged support of the local population (Gursoy and Rutherford, 2004).

Tourism literature reveals that the residents' attitudes towards tourism play an important role in the sustainable management of tourist destinations (Gursoy and Rutherford, 2004; Sharma and Dyer, 2012). It is of crucial importance that tourism planners understand how the communities perceive tourism to determine what they have to do in order to have the support of the local population in tourism related initiatives (Harrill, 2004).

The residents' involvement in tourism decision-making becomes useful in influencing and shaping how the local community perceives the impacts of tourism (Bonimy, 2008 in Sharma and Dyer, 2012).

\subsection{Economic dependence, the impacts of tourism and residents' support to STD}

Economic dependence translates as the extent to which the residents' income or the residents' families income is dependent on activities related to tourism (Chen and Chen, 2010; Perdue et al. 1990). The level of economic dependence is used to classify whether the residents are involved in tourism or not (Chen and Chen, 2010), and whether their income/employment depends on the tourism industry or not.

For some time now, the concept of economic dependence on tourism has attracted the interest of researchers, particularly when they attempt to predict attitudes based on the economic benefits or the economic capacity of a community (Harrill, 2004). The author argues that, as a consequence, tourism researchers have analysed the associations between the residents' perceptions and their economic dependence through diverse perspectives, from a single individual to an entire community.

According to the theoretical and conceptual framework provided by the social exchange theory, previous studies have identified economic dependence on tourism as one of the factors that are likely to influence the perception of the impacts of tourism 
(Andriotis and Vaughan, 2003; Brida et al., 2011; Chen and Chen, 2010; Ko and Stewart 2002; Ling et al., 2011; Perdue et al., 1990; Vargas-Sánchez et al., 2011).

Most of the research studies focusing on this relationship have concluded that the residents who are most dependent on tourism or hope to obtain personal benefits from this activity, tend to perceive greater impacts (Lankford and Howard, 1994; Ling et al., 2011). If residents depend on tourism-based employment they will have a greater propensity to recognise its benefits (García et al., 2015). Kuvan and Akan (2005) argue that residents with jobs related to tourism, when compared to other residents who are not dependent on the tourism industry, exhibit not only more positive attitudes, but also tend to disapprove less of the negative effects. In the study of Chen and Chen (2010), applied to Tainan city, the authors concluded that economic dependence has significant effects on the positive impacts of tourism, whereas the effect of economic dependence on the negative impacts of tourism is not significant. Ko and Stewart (2002) have found that personal benefits from tourism development have an effect on positive impacts of tourism. Nonetheless, their study did not find a significant relationship between personal benefits from tourism development and perceptions of the negative impacts of tourism. Similar results were obtained by Ling et al. (2011) in his study. Liu and Var's (1986) study observed that dependence on tourism does not seem to be a significant factor.

The more dependent residents are on tourism for their economic welfare, the more collaborative they are in tourism development (Chen and Chen, 2010; Lankford and Howard, 1994). Agents economically tied to the tourism industry tend to support tourism development (Harrill, 2004), given that the industry brings economic benefits, such as employment opportunities, personal income, among others (Ling et al., 2011). Haley et al. (2005) concluded that economic reliance (measured by two items: 'importance of tourism to occupation' and 'employed in the tourism industry') is a predictor of tourism development support. The study of Chen and Chen (2010) demonstrated that economic dependence has an indirect effect on tourism development support via the mediation of positive impacts of tourism. Also, Ko and Stewart (2002) found that residents that depend on tourism-based employment tend to be more favourably disposed towards tourism development. The study of Ling et al. (2011) showed that there is a significant relationship between personal benefit and additional support to tourism development. Vargas-Sánchez et al. (2011) also concluded that personal benefits derived from tourism development are related, in a positive manner, to a favourable attitude towards additional tourism development.

As we can see, previous research has examined the relationship between economic dependence and residents' support to tourism development. We expect similar results when sustainability issues are integrated into tourism development initiatives. That is, the support residents give to STD will be influenced by their economic dependence on tourism.

Based on the preceding discussion, the following hypotheses are proposed:

H1 Residents' economic dependence on tourism influences their perceptions of the positive impacts of tourism.

H2 Residents' economic dependence on tourism influences their perceptions of the negative impacts of tourism.

H3 Residents' economic dependence on tourism influences their support to STD. 


\subsection{Local government management of tourism, perceptions of the impacts of tourism and residents' support to STD}

Government management of tourism has a key role in designing a sustainable model for the destination (Gorica et al., 2012). Governments are key players in this process, because they are responsible for territorial development and it is their responsibility to provide the necessary conditions for the sustainable development of tourism. Intervention and regulation by the government, especially on a local level, are a requirement for 'effective management systems for STD' [Ruhanen, (2013), p.81).

Many of the structural plans for the protection and preservation of historical destinations require a leadership that, in most cases, is the government's responsibility, especially on a local level. Local government has been acknowledged as the most important authority in developing effective tourism development policies, because "it is at this level where the impacts of tourism development are felt most acutely" [Madrigal, (1995), p.87]. Therefore, it is natural for the local community to consider cooperative tourism planning as crucial for reducing the negative impacts of tourism development. Local authorities should provide an enabling and encouraging context for an effective management of the impacts of tourism. Therefore, it is expected for the way residents perceive a government's competence in managing tourism to influence their perceptions of the impacts of tourism.

Madrigal's (1995) study results indicate there are different residents' segments according to their perceptions of tourism development and that each group has different expectations about the government's role in developing them. Assante et al. (2012a, $2012 \mathrm{~b}$ ) tested and empirically confirmed the positive relationship between government management of tourism and the perception of its environmental impacts. The same authors concluded that residents tend to be more receptive of tourism impacts when they feel the government is an effective manager.

STD requires cooperation efforts between the local tourist destination's stakeholders. Knowing and understanding the various stakeholders' attitudes towards sustainable tourism initiatives will help to implement successful policies designed to encourage the adoption of STD principles (Brokaj, 2014). The author argues that governments are responsible for providing an environment that allows and encourages the local community and other stakeholders 'to respond to sustainability issues' [Brokaj, (2014), p.110). Local authorities can play a significant role in supporting and encouraging that kind of environment (Gorica et al., 2012). Essentially, we can expect there to be a relationship between the local government's management of tourism and residents' support to STD. In other words, it is expected the local government's perceived ability to effectively manage tourism influences residents' support to STD.

Assante et al. (2012a, 2012b) argue that, in order to achieve consensus on how to manage future tourism developments, government management and stakeholders' cooperation is necessary. The authors conclude that, if residents perceive that there is an effective management of tourism by the public administration agents, they will tend to have more positive feelings about STD. The results of both studies indicated that residents' perceptions of government efficiency of tourism development management were strongly associated with positive attitudes towards STD, whereas, residents who felt the government did not efficiently manage tourism development had more negative attitudes towards STD (Assante et al., 2012a, 2012b; Lottig, 2007). 
Considering all the information previously discussed, we established the following hypotheses:

H4 Residents' perception of effective local government management of tourism influences their perception of the positive impacts of tourism.

H5 Residents' perception of effective local government management of tourism influences their perception of the negative impacts of tourism.

H6 Resident's perception of effective local government management of tourism influences their support to STD.

\subsection{Perceived impacts of tourism and residents' support to STD}

Over the past two decades several authors have conducted studies on the relationship that can be established between the residents' perceptions, the impacts of tourism and residents' support for the development of tourism (Brida et al., 2011; Cañizares et al., 2014; García et al., 2015; Gursoy et al., 2002 ; Gursoy and Rutherford, 2004; Ko and Stewart, 2002; Látková and Vogt, 2012; Nicholas et al., 2009; Nunkoo and Ramkissoon, 2010; Sharma and Dyer, 2009; Stylidis et al., 2014). These studies, based on the social exchange model, suggest that the way residents perceive the elements of exchange influence the manner in which they react to tourism (Andriotis and Vaughan, 2003). Those reactions become apparent in residents' support or opposition to tourism development (Nunkoo, 2012).

Support to tourism development is influenced by the residents' perceptions of the positive and negative impacts of tourism (Gursoy et al., 2010; Nunkoo, 2012; Stylidis et al., 2014), on the economic, socio-cultural and environmental dimensions. Regarding economic impacts, tourism can boost employment opportunities and additional income but it can also increase the fiscal burden, inflation and the local governments' debt. As for the socio-cultural impacts, the most common positive consequences are the revival of local traditions and festivities, inter-culturalism, and the cultivation of pride and cultural identity. On the other hand, there are the negative socio-cultural impacts, such as traffic congestion and parking issues, crime and acculturation phenomena, and a loss of identity. Regarding environmental impacts, there have been a few steps taken towards the protection of nature its landscape, flora and wildlife; among the negative impacts of tourism on the environment there is pollution, landscape degradation and the consequent destruction of wildlife (Andereck et al. 2005; García et al., 2015).

Previous studies suggest that residents who perceive positive impacts of tourism are more likely to support tourism development, i.e., stronger perceptions of the benefits of tourism are more likely to lead to higher support of tourism development, while weaker perceptions of the benefits of tourism are more likely to lead to lower support of tourism development (Nunkoo, 2012). On the subject of negative impacts of tourism, Nunkoo (2012) mentions the need to carry out further research on the relationship between the residents' perceptions of tourism costs and their support to tourism development, given that the studies conducted until now have been inconclusive. The author argues that while there are some empirical studies that confirm the existence of a negative relationship between the residents' perceptions of tourism costs and the support they give to tourism development (for example, Gursoy et al., 2010; Gursoy and Rutherford, 2004; Ko and Stewart, 2002; Látková and Vogt, 2012; Perdue et al., 1990), some other research reveals 
that perceptions of the negative impacts have an insignificant relationship with support for tourism development (Dyer et al., 2007; Gursoy et al., 2002; Ling et al., 2011).

In this study, the 'object' of support refers to STD. Thus, this study tries to focus on the premise that residents' support to STD may be affected by the perception of both the negative and the positive impacts of tourism (economic, socio-cultural and environmental). Therefore, based on the social exchange model, there will always be groups of residents who support the sustainable development of tourism when they realise the exchange is beneficial for the community's well-being, while others will oppose it when they feel the exchange can be harmful (Cañizares et al., 2014).

In this context, the literature's conceptual and empirical perspective led to the following hypotheses:

H7 Residents' perception of the positive impacts of tourism influences their support to STD.

H8 Residents' perception of the negative impacts of tourism influences their support to STD.

Figure 1 illustrates this study's theoretical framework and the proposed hypotheses.

Figure 1 Proposed theoretical framework

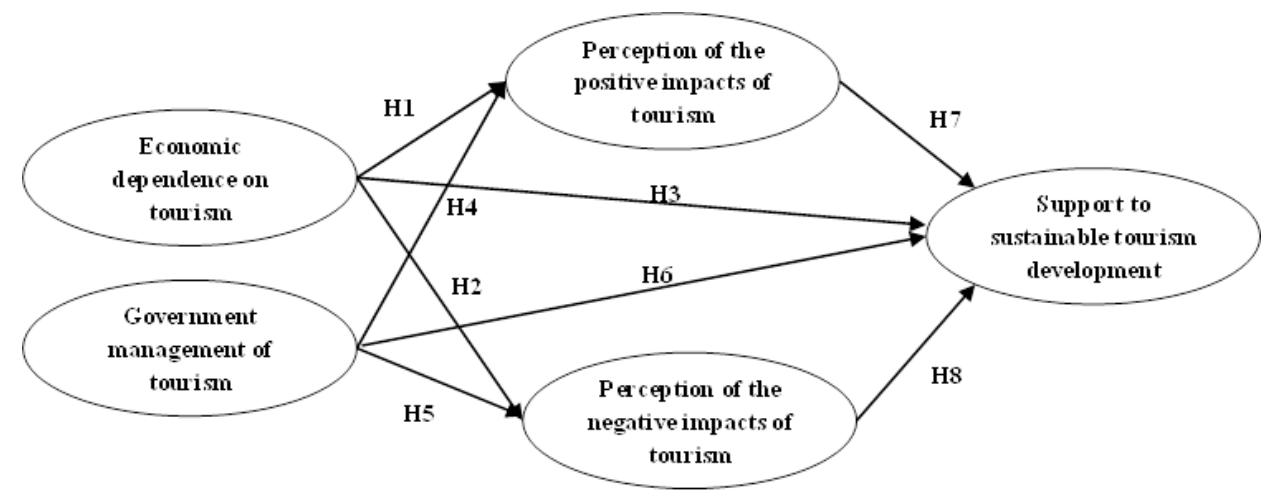

\section{Methodology}

\subsection{Study location}

This study was conducted at a small historic town in northern Portugal, Lamego, located within the Douro Valley World Heritage site. Lamego is one of the most ancient towns in Portugal, with a variety of historic heritage that chronicles several historic stages. Accordingly, the Chapel of S. Pedro Balsemão (7th century), the Castle (10th century), the Cistern (10th century), the Cathedral (12th century), the Church of Santa Maria Maior de Almacave (12th-13th century), constitute important national heritage monuments. One of the most visited monuments is the Sanctuary of Nossa Senhora dos Remédios (18th century). This town has about 12,214 inhabitants in an area of 20.20 square kilometres divided into two sub-municipalities (INE, 2012). The local economy is mainly dependent on services, small businesses and agriculture. 
The development of the tourism industry in Lamego is a recent phenomenon. The nomination by UNESCO of the Douro Valley region as World Heritage site, in December 2001, boosted tourism in this historic town. Now, Lamego is attracting an increasing amount of visitors and is the municipality that retains more domestic and foreign tourists in the Douro region (CCDRN, 2012).

Several public and private organisations have undertaken a process of revitalisation of the town's heritage, particularly after the Douro Valley region's classification as World Heritage site, and the structural funds for the conservation and rehabilitation of heritage were made available by the European Union (Vieira et al., 2014). Since 2012, Lamego's local authorities have worked on the conservation and restoration of monuments and in the dissemination of the town as a tourist destination. To this end, they have implemented a program ('Living Lamego - valuing and integrating the Historic Centre of Lamego'), financed by the European Union, with the purpose of reaffirming Lamego as cultural heritage and architectonic site (Municipality of Lamego, 2013). The program was based on two intervention plans that targeted the sustainability of this tourist destination. Firstly, the program aimed at increasing the local population's quality of life and its qualification in various aspects (cultural, social, economic and environmental). Secondly, the plan aimed at reinforcing the town's attractiveness and external visibility, taking advantage of its heritage and of the territory's specific characteristics, thus contributing to the creation of different economic activities, particularly tourism related activities, consequently retaining the population in the territory (Municipality of Lamego, 2013).

Residents' participation in this program was very scarce, which led the local community to react negatively to this tourism strategy. At the project's initial stages, all stakeholders, especially the local population, were involved. However, the residents' expectations were not met due to a series of factors, such as, inexistent funding for rehabilitating the old town's buildings' facades; constraints to internal mobility; delays in the rehabilitation works which affected local businesses and consequently led to an increase in unemployment. These facts diminished institutional cooperation.

In the study by Vieira et al. (2014), at Lamego's historic town, key stakeholder groups such as heritage managers, tour operators and local authorities, were interviewed for the purposes of assessing their views on the STD concept and to understand their interest and future prospects for STD. This study's results highlight the communication problems that occurred between the various stakeholders. Even though the local authorities tried to implement a tourism development plan that took issues related to sustainability into consideration, its implementation proved to be complex and was not successful as a whole. The existence of gaps between strategy and implementation (Khairat and Maher, 2012) has limited the application of STD actions in this town.

In this context, this small historic town was chosen because of its rich historic heritage and cultural worth, where any existing resources, barely developed as historic products, may represent an opportunity for tourism to grow. Its authenticity and singularity are factors of attraction that contrast with other artificial destinations (Choay, 2010). Moreover, considering the destination's life cycle proposed by Butler (1980), this town is in a developmental stage where the negative impacts of tourism go almost unnoticed by all of those involved. Considering this, we believe that it is important to assess if the residents support the local government's actions concerning STD strategies. 


\subsection{Sampling and data collection}

This study adopted a quantitative approach, in the form of a survey questionnaire. The target population are the historic town of Lamego's permanent residents, any who have been residing for more than a year, who are 18 years old or older. Due to time and financial constraints, face-to-face survey administration was limited to a convenience sample. In view of the fact that the main data analysis technique in this study is structural equation modelling, we targeted a sample size of at least 300 respondents to comply with the requirements of this technique (Hair et al., 2010). In order to create the sample, 14 undergraduate students completing their degree in Tourism, Culture and Heritage Management received specific training to be able to apply the surveys. The students were residing in Lamego and were divided by the two existing sub municipalities - Almacave and Sé. One of the students was responsible for applying the survey to key informants, such as heritage managers, local authority representatives, and economic agents directly involved in the industry, that were also members of the local community. These key informants were selected based on a purposeful sampling of individuals with expertise/detailed knowledge on the subjects under analysis.

The survey was distributed and collected by the undergraduate students at the residents' homes, workplaces, restaurants, secondary schools, and The Higher Education School of Technology and Management. Out of the 350 residents approached, only 325 agreed to participate in the study. After establishing accuracy and completeness, a total of 300 surveys were retained and used for subsequent data analysis, yielding a response rate of $92 \%$. Even though there is a high response rate, the convenience sampling method requires some caution regarding the findings' generalisation.

\subsection{Questionnaire development}

A structured questionnaire was developed consisting of several questions related to the local population's perceptions regarding economic dependence, the local government's management of tourism, the perceived impacts of tourism and support to STD. Key background information on the respondents, such as age, gender, education level, household income and occupation was also included in the survey. A seven-point Likert type scale $(1=$ strongly disagree; $7=$ strongly agree $)$ was used for all the variables except for economic dependence $(1=$ no relation; 7 = entirely related $)$.

Scales for assessing the impacts of tourism and STD previously used in other studies were adopted to measure the constructs proposed in this study. According to our literature review, the following studies were chosen for the selection of the measurement scales: [Chen and Chen, 2010; Assante et al., 2012a, 2012b; Lee, 2013 (Table 1)]. Scales' selection was also based on studies that used multivariate statistical analysis, in concordance with those this study uses. Over the next paragraphs, clarification about the measurement scales used in this study will be given.

- Economic dependence: According to the literature, the economic dependence variable measurement differs from others in the type and number of related items. For example, in the study of Vareiro and Mendes (2015), economic dependence on tourism was analysed as a dichotomous question, which was part of the respondents' socio-demographic profile. The study of Nunkoo and Ramkissoon (2010) also considers economic dependence a profile variable with two possible answers: 
dependent and independent. Mazón et al. (2009) uses both an objective (whether the income is directly related or not) and a subjective (the respondents' self-perception) measure for economic dependence on the tourism industry. Other studies (Ko and Stewart, 2002; Chen and Chen, 2010; Látková and Vogt, 2012) applying the structural equation modelling methods, measure the construct of economic dependence on tourism (or similar concepts like 'dependency on tourism', 'employment dependency on tourism', 'personal benefits of tourism development'; 'personal economic reliance') based on two items. In this study, the economic dependence variable was measured with the scale proposed by Chen and Chen (2010). This variable assesses the dependence of respondents' income and employment on the tourism industry, comprising two items: "My job is closely related to the tourism industry" and "My household income is closely tied to the tourism industry". This is a respondents' self-perception measure regarding the association between their work, household income, and the tourism industry.

- Local government management of tourism: This variable was measured according to the scale proposed in the study of Assante et al. (2012a, 2012b). The authors developed and tested a model adapted from Ko and Setwart (2002). Government management of tourism was one of the important factors identified, and was measured according to three items. Regarding the original instrument, adjustments were made to take into consideration the local government's activities rather than the central government's activities. Specifically, the word 'state government' was replaced with the word 'local government'. In the study of Assante et al. (2012a, 2012b), the Cronbach's alpha score for this latent variable was 0.77 .

- Perceptions of the (positive and negative) impacts of tourism: Chen and Chen's (2010) scale for perceptions of the impacts of tourism with 27 items was used. The authors, based on Ko and Stewart (2002) and on Easterling (2004 in Chen and Chen, 2010), included the economic impact (nine items), the social/cultural impact (ten items) and the environmental impact (eight items) in this scale. Moreover, this scale, and its respective indicators, was considered suitable for this historic town's context, i.e., its items are well adapted to the town's reality concerning the consequences of tourism development initiatives.

- Support to STD: This six-item scale was designed to assess the extent of a resident's intention to support sustainable tourism development, based on the findings of Nicholas et al. (2009). In the study of Lee (2013), the Cronbach's alpha score for this latent variable was 0.91 .

Table 1 Variables' operationalisation

\begin{tabular}{ll}
\hline Variable & \multicolumn{1}{c}{ Operationalisation } \\
\hline Economic dependence & $\begin{array}{l}\text { Scale proposed by Chen and Chen (2010) consisting of two } \\
\text { items. }\end{array}$ \\
Local government & The three items used to measure this construct were adopted \\
management of tourism & from Assante et al. (2012a, 2012b). \\
Perceptions of the positive & Scale proposed by Chen and Chen (2010). This scale consists of \\
impacts of tourism & 15 items. \\
Perceptions of the negative & Scale proposed by Chen and Chen (2010). This scale consists of \\
impacts of tourism & 12 items. \\
Support to STD & Six items' scale proposed by Lee (2013). \\
\hline
\end{tabular}




\subsection{Data analysis}

In order to test the hypothesised correlations between the constructs, we used the structural equation modelling methods. Firstly, a confirmatory factor analysis (CFA) was used to provide a confirmatory test of the measurement theory. The quality of the measurement model was assessed through an analysis of the convergent and discriminant validity of each construct. Secondly, a structural model with the hypothesised relationships was estimated. Both measurement and structural models were estimated with the maximum likelihood method. To assess the goodness-of-fit of the estimated models, we analysed the chi-square value $\left(\chi^{2}\right)$, the degrees of freedom $(d f)$ and the ratio $\chi^{2} / d f$; the comparative fit index $(\mathrm{CFI})$; the root mean square error of approximation (RMSEA). The descriptive analysis was performed using SPSS - version 22 for Windows, and the structural equation models were carried out using Amos - version 22 for Windows.

Table 2 Respondents' profile $(\mathrm{N}=300)$

\begin{tabular}{|c|c|}
\hline Variable & Characteristics \\
\hline \multirow[t]{2}{*}{ Gender } & Female $(51.9 \%)$ \\
\hline & Male (48.1\%) \\
\hline \multirow[t]{2}{*}{ Age (years) } & Minimum $=18 ;$ maximum $=81$ \\
\hline & Mean $=37.5 ;$ standard deviation $=14.1$ \\
\hline \multirow[t]{2}{*}{ Place of birth } & In the region $(78.7 \%)$ \\
\hline & Somewhere else $(21.3 \%)$ \\
\hline \multirow{2}{*}{$\begin{array}{l}\text { Time in the } \\
\text { community (years) }\end{array}$} & Minimum $=1 ;$ maximum $=81$ \\
\hline & Mean $=28.8 ;$ standard deviation $=18.4$ \\
\hline \multirow[t]{3}{*}{ Education } & Middle school or under $(26.0 \%)$ \\
\hline & Secondary school (41.8\%) \\
\hline & University degree $(32.2 \%)$ \\
\hline \multirow[t]{4}{*}{ Employment status } & Employed (63.3\%) \\
\hline & Students $(22.3 \%)$ \\
\hline & Unemployed (7.8\%) \\
\hline & Retired (6.7\%) \\
\hline \multirow{3}{*}{$\begin{array}{l}\text { Monthly income } \\
\text { (in Euros) }\end{array}$} & $\leq 1,500(67.6 \%)$ \\
\hline & $1,501-3,000(28.5 \%)$ \\
\hline & $>3,000(3.9 \%)$ \\
\hline
\end{tabular}

\section{Empirical results}

\subsection{Respondents' profile}

From the 300 residents included in the sample, 51.9\% were female and $48.1 \%$ were male, with ages between 18 and 81 years old $(\mathrm{M}=37.5 ; \mathrm{SD}=14.1)$. The majority was born in the region $(78.8 \%)$ and the average period of residency was 28.8 years. The most 
frequent level of education was secondary school (41.8\%), followed by university degree $(32.2 \%)$ and middle school or under $(26.0 \%)$. More than a half were employed $(63.3 \%)$ and/or had a monthly income equal to or under 1,500 Euros (67.6\%) (Table 2).

\subsection{Descriptive analysis}

Table 3 shows the variables' descriptive analysis. The residents' economic dependence on tourism was measured on a seven-point scale from $1=$ 'no relation' to $7=$ 'entirely related', and resulted in a mean value of 4.08. The respondents' perceptions of their economic dependence on tourism are not very high. As we've previously explained, this is a town where the tourism sector still is not developed.

Regarding the local government management of tourism variable, the residents' perceptions of the local government's ability to manage tourism efficiently resulted in a relatively low mean value (overall mean value $=3.19$ ). All the items registered mean values under 4. Most of the respondents believe the local government does not take their concerns about tourism into account, that the quality of the public services did not improve and that the local government does not do a good job at balancing both the residents' and the tourists' needs.

The residents' support to STD scale obtained a mean value of 3.45. Clearly, the five items' mean values are not very high. The highest mean value, 4.38 , was for the first item ("I support the development of community-based sustainable tourism initiatives"). The third item had the lowest mean value (2.64) ("I participate in cultural exchanges between local residents and visitors"). Generally, there was not a very high support to STD (mean value $=3.45$ ).

Table 3 also shows the overall mean of the perceived impacts of tourism (both positive and negative). The overall mean of the positive impacts of tourism is 4.40 (4.59 for positive economic impacts of tourism; 4.29 for positive social-cultural impacts of tourism; and 4.24 for positive environmental impacts of tourism). The respondents recognised the economic, socio-cultural and environmental benefits of tourism and agreed with all the positive impacts of tourism's statements. Similarly to the results obtained by Nunkoo and Ramkissoon (2010), economic impacts are most favourably perceived by local residents - they felt that tourism is useful for promoting local products (mean value $=5.49$ ).

The most valued socio-cultural positive impacts of tourism are related to the increase in local cultural identity (mean value $=4.60$ ) and an increase in the knowledge on local heritage (mean value $=4.47$ ). Regarding the environmental benefits, the respondents felt that tourism has raised awareness on heritage resources' protection (mean value $=4.47$ ).

The respondents disagreed with nearly all the statements regarding the negative impacts of tourism (mean value $=2.96$ ), particularly with those related to the socio-cultural impacts of tourism (increased crime rates and prostitution, increased disagreements between visitors and residents and reduced local safety).

The results revealed that residents tend to disagree more with the negative impacts. Locals that responded to the survey perceived the negative impacts far less than they did the positive. 
Table 3 Descriptive analysis $(\mathrm{N}=300)$

\begin{tabular}{|c|c|c|}
\hline Variables and items & Mean & Std. deviation \\
\hline Economic dependence on tourism* & 4.08 & 2.40 \\
\hline My job is closely related to the tourism industry & 4.22 & 2.49 \\
\hline My household income is closely tied to the tourism industry & 3.93 & 2.55 \\
\hline Local government management of tourism $* *$ & 3.19 & 1.51 \\
\hline $\begin{array}{l}\text { The local government does a good job balancing both residents' and } \\
\text { tourists' needs }\end{array}$ & 3.32 & 1.69 \\
\hline $\begin{array}{l}\text { The local government listens to residents regarding their concerns } \\
\text { about tourism }\end{array}$ & 2.98 & 1.66 \\
\hline $\begin{array}{l}\text { The quality of public services has improved in Lamego because of } \\
\text { tourism }\end{array}$ & 3.26 & 1.66 \\
\hline Support to sustainable tourism development ${ }^{* *}$ & 3.45 & 1.27 \\
\hline $\begin{array}{l}\text { I support the development of community-based sustainable tourism } \\
\text { initiatives }\end{array}$ & 4.38 & 1.81 \\
\hline I participate in sustainable tourism-related plans and development & 2.85 & 1.59 \\
\hline I participate in cultural exchanges between local residents and visitors & 2.64 & 1.56 \\
\hline I cooperate with tourism planning and development initiatives & 2.94 & 1.72 \\
\hline $\begin{array}{l}\text { I participate in the promotion of environmental education and } \\
\text { conservation }\end{array}$ & 3.10 & 1.74 \\
\hline Perceptions of the positive impacts of tourism $* *$ & 4.40 & 1.17 \\
\hline PECIT: tourism has increased job opportunities in your community & 4.36 & 1.54 \\
\hline PECIT: tourism has created more tax revenue for the local government & 4.45 & 1.44 \\
\hline PECIT: tourism is useful for promoting local products & 5.49 & 1.44 \\
\hline PECIT: tourism has improved the residents' standard of living & 4.44 & 1.58 \\
\hline PECIT: tourism has generated economic benefits for local people & 4.43 & 1.51 \\
\hline PECIT: tourism has generated economic benefits for small businesses & 4.37 & 1.50 \\
\hline $\begin{array}{l}\text { PSCIT: tourism has encouraged the residents' participation in cultural } \\
\text { activities }\end{array}$ & 4.36 & 1.46 \\
\hline PSCIT: tourism has enriched local nightlife & 3.99 & 1.77 \\
\hline PSCIT: tourism has led to a balanced local community development & 4.05 & 1.39 \\
\hline PSCIT: tourism has increased knowledge about the local heritage & 4.47 & 1.46 \\
\hline PSCIT: tourism has increased local cultural identity & 4.60 & 1.45 \\
\hline PEIT: tourism has improved access to intercity transports & 3.92 & 1.53 \\
\hline $\begin{array}{l}\text { PEIT: tourism has increased the number of infrastructures and } \\
\text { facilities }\end{array}$ & 4.23 & 1.52 \\
\hline PEIT: tourism has raised awareness on heritage resources' protection & 4.47 & 1.41 \\
\hline $\begin{array}{l}\text { PEIT: tourism has increased the number of local recreational facilities } \\
\text { and resources }\end{array}$ & 4.34 & 1.55 \\
\hline
\end{tabular}

Notes: *Measured on a seven-point scale from $1=$ 'no relation' to $7=$ 'entirely related'. **Measured on a seven-point scale from $1=$ 'strongly disagree' to $7=$ 'strongly agree'.

NECIT: Negative economic impacts of tourism; NSCI: negative socio-cultural impacts of tourism; NEIT: Negative environmental impacts of tourism. PECIT: Positive economic impacts of tourism; PSCIT: Positive socio-cultural impacts of tourism; PEIT: positive environmental impacts of tourism. 
Table 3 Descriptive analysis $(\mathrm{N}=300)$ (continued)

\begin{tabular}{lcc}
\hline Variables and items & Mean & Std. deviation \\
\hline Perceptions of the negative impacts of tourism ${ }^{* *}$ & 2.96 & 1.16 \\
NECIT: tourism has raised the prices of local goods & 3.86 & 1.56 \\
$\begin{array}{l}\text { NECIT: tourism has deepened the economic inequalities among } \\
\text { residents }\end{array}$ & 3.28 & 1.40 \\
NECIT: tourism has the increased residents' cost of living & 3.37 & 1.46 \\
$\begin{array}{l}\text { NSCIT: tourism has destroyed the quality of the town for residential } \\
\text { purposes }\end{array}$ & 2.78 & 1.39 \\
NSCIT: tourism has increased crime rates and prostitution & 2.25 & 1.41 \\
NSCIT: tourism has reduced local safety & 2.32 & 1.37 \\
NSCIT: tourism has increased disagreements between visitors and & 2.29 & 1.39 \\
residents & & \\
NSCIT: tourism has overused the local heritage's resources & 3.09 & 1.59 \\
NEIT: tourism has increased traffic congestion and parking problems & 3.56 & 1.97 \\
NEIT: tourism has increased litter and pollution & 3.27 & 1.89 \\
NEIT: tourism has destroyed the local way of life & 2.65 & 1.56 \\
NEIT: tourism has disrupted the lives of local residents and created & 2.81 & 1.62 \\
inconvenience & & \\
\hline
\end{tabular}

Notes: *Measured on a seven-point scale from $1=$ 'no relation' to $7=$ 'entirely related'.

**Measured on a seven-point scale from 1 = 'strongly disagree' to 7 = 'strongly agree'.

NECIT: Negative economic impacts of tourism; NSCI: negative socio-cultural impacts of tourism; NEIT: Negative environmental impacts of tourism. PECIT: Positive economic impacts of tourism; PSCIT: Positive socio-cultural impacts of tourism; PEIT: positive environmental impacts of tourism.

\subsection{Measurement model (CFA)}

The instruments' quality was assessed using CFA through the estimation of a measurement model with the maximum likelihood method. The items and constructs were operationalised according to the literature, assuming correlations between the constructs.

The initial CFA model led to dropping one item ("I obey regulatory environmental standards to reduce the negative impacts of tourism") from the construct 'support to STD' due to its low factor loading. The Chi-square test of the resulting measurement model $\left(\chi^{2}=1217.865 ; d f=577 ; p<0.001\right)$ was significant, but the Chi-square/df ratio $\left(\chi^{2} / d f=2.111\right)$ was lower than the threshold suggested by some authors (Hair et al., 2010; Kline, 2005). The comparative fit index $(\mathrm{CFI}=0.930)$ and the root mean square error of approximation $(\mathrm{RMSEA}=0.061)$ were also within the recommended values (Marôco, 2010). Given the sample size and the number of items, the model fit indices suggest the measurement model fits the sample data correctly (Hair et al., 2010). 
Table 4 Standardised factor loadings, average variance extracted (AVE) and construct reliability (CR) of the measurement model

\begin{tabular}{|c|c|c|c|}
\hline Constructs and items & Factor loadings & $A V E$ & $C R$ \\
\hline Perceptions of the positive impacts of tourism ${ }^{(1)}$ & & 0.579 & 0.953 \\
\hline Tourism has increased job opportunities in your community & 0.647 & & \\
\hline $\begin{array}{l}\text { Tourism has created more tax revenue for the local } \\
\text { government }\end{array}$ & 0.650 & & \\
\hline Tourism is useful for promoting local products & 0.602 & & \\
\hline Tourism has improved the residents' standard of living & 0.781 & & \\
\hline Tourism has generated economic benefits for local people & 0.799 & & \\
\hline $\begin{array}{l}\text { Tourism has generated economic benefits for small } \\
\text { businesses }\end{array}$ & 0.787 & & \\
\hline $\begin{array}{l}\text { Tourism has encouraged the residents' participation in } \\
\text { cultural activities }\end{array}$ & 0.744 & & \\
\hline Tourism has enriched local nightlife & 0.671 & & \\
\hline Tourism has led to a balanced local community development & 0.833 & & \\
\hline Tourism has increased knowledge about the local heritage & 0.808 & & \\
\hline Tourism has increased local cultural identity & 0.790 & & \\
\hline Tourism has improved access to intercity transports & 0.744 & & \\
\hline $\begin{array}{l}\text { Tourism has increased the number of infrastructures and } \\
\text { facilities }\end{array}$ & 0.813 & & \\
\hline $\begin{array}{l}\text { Tourism has raised awareness for heritage resources' } \\
\text { protection }\end{array}$ & 0.850 & & \\
\hline $\begin{array}{l}\text { Tourism has increased the number of local recreational } \\
\text { facilities and resources }\end{array}$ & 0.840 & & \\
\hline Perceptions of the negative impacts of tourism (1) & & 0.510 & 0.925 \\
\hline Tourism has raised the prices of local goods & 0.621 & & \\
\hline $\begin{array}{l}\text { Tourism has deepened the economic inequalities among } \\
\text { residents }\end{array}$ & 0.616 & & \\
\hline Tourism has increased the residents' cost of living & 0.674 & & \\
\hline $\begin{array}{l}\text { Tourism has destroyed the quality of the town for residential } \\
\text { purposes }\end{array}$ & 0.815 & & \\
\hline Tourism has increased crime rates and prostitution & 0.747 & & \\
\hline Tourism has reduced local safety & 0.775 & & \\
\hline $\begin{array}{l}\text { Tourism has increased disagreements between visitors and } \\
\text { residents }\end{array}$ & 0.768 & & \\
\hline Tourism has overused the local heritage's resources & 0.698 & & \\
\hline $\begin{array}{l}\text { Tourism has increased traffic congestion and parking } \\
\text { problems }\end{array}$ & 0.692 & & \\
\hline Tourism has increased litter and pollution & 0.651 & & \\
\hline Tourism has destroyed the local way of life & 0.759 & & \\
\hline $\begin{array}{l}\text { Tourism has disrupted the lives of local residents and created } \\
\text { inconvenience }\end{array}$ & 0.719 & & \\
\hline
\end{tabular}

Notes: ${ }^{(1)}$ Measured on a seven-point scale from $1=$ 'strongly disagree' to $7=$ 'strongly agree'.

${ }^{(2)}$ Measured on a seven-point scale from $1=$ 'no relation' to 7 = 'entirely related'. 
Table 4 Standardised factor loadings, average variance extracted (AVE) and construct reliability (CR) of the measurement model (continued)

\begin{tabular}{|c|c|c|c|}
\hline Constructs and items & Factor loadings & $A V E$ & $C R$ \\
\hline Economic dependence $^{(2)}$ & & 0.812 & 0.896 \\
\hline My job is closely related to the tourism industry & 0.912 & & \\
\hline My household income is closely tied to the tourism industry & 0.890 & & \\
\hline Local government management of tourism ${ }^{(1)}$ & & 0.741 & 0.895 \\
\hline $\begin{array}{l}\text { The local government does a good job at balancing both } \\
\text { residents' and tourists' needs }\end{array}$ & 0.892 & & \\
\hline $\begin{array}{l}\text { The local government listens to residents regarding their } \\
\text { concerns about tourism }\end{array}$ & 0.877 & & \\
\hline $\begin{array}{l}\text { The quality of public services has improved in Lamego } \\
\text { because of tourism }\end{array}$ & 0.811 & & \\
\hline Support to sustainable tourism development $t^{(1)}$ & & 0.620 & 0.889 \\
\hline $\begin{array}{l}\text { I support the development of community-based sustainable } \\
\text { tourism initiatives }\end{array}$ & 0.570 & & \\
\hline $\begin{array}{l}\text { I participate in sustainable tourism-related plans and } \\
\text { development }\end{array}$ & 0.828 & & \\
\hline $\begin{array}{l}\text { I participate in cultural exchanges between local residents } \\
\text { and visitors }\end{array}$ & 0.752 & & \\
\hline $\begin{array}{l}\text { I cooperate with tourism planning and development } \\
\text { initiatives }\end{array}$ & 0.897 & & \\
\hline $\begin{array}{l}\text { I participate in the promotion of environmental education and } \\
\text { conservation }\end{array}$ & 0.847 & & \\
\hline
\end{tabular}

Notes: ${ }^{(1)}$ Measured on a seven-point scale from $1=$ 'strongly disagree' to $7=$ 'strongly agree'.

${ }^{(2)}$ Measured on a seven-point scale from $1=$ 'no relation' to 7 = 'entirely related'.

To assess convergent validity we analysed the standardised factor loadings, the average variance extracted (AVE) and the construct reliability (CR) (Table 4). The standardised factor loadings were all statistically significant $(p<0.001)$ and ranged from 0.602 to 0.912 , above the cut off point of 0.50 suggested by Hair et al (2010). The AVE measures the amount of variance explained by the construct and should be higher than 0.50 . In this study, the AVE ranged from 0.510 and 0.812 , over the cut off point. The CR estimates, over 0.88 , suggest high construct reliability, which indicates that internal consistency exists - i.e., all the measures consistently represent the same construct (Hair et al., 2010). These results constitute evidence of the constructs' convergent validity.

The discriminant validity was verified by comparing the square root of the AVE values of any two constructs with the correlation estimate between these constructs. According to Hair et al. (2010), the square root of the AVE estimates should be higher than the correlation estimate. The values in Table 5 show that all the constructs met this criterion, providing evidence of discriminant validity. 
Table 5 Correlations between the constructs and the square root of average variance extracted.

\begin{tabular}{llccccc}
\hline Constructs & 1 & 2 & 3 & 4 & 5 \\
\hline 1 & Perceptions of the positive impacts of tourism & 0.761 & & & & \\
2 & Perceptions of the negative impacts of tourism & 0.248 & 0.714 & & & \\
3 & Economic dependence & -0.040 & 0.070 & 0.901 & & \\
4 & Local government management of tourism & 0.544 & 0.178 & -0.130 & 0.861 & \\
5 & Support to STD & 0.372 & 0.154 & -0.027 & 0.338 & 0.787 \\
\hline
\end{tabular}

Note: Diagonal values indicate the square root of average variance extracted for each construct.

Overall, these results showed that the measurement model had adequate psychometric requirements with convergent and discriminant validity.

\subsection{Structural model and hypotheses testing}

The structural model was estimated to test the hypothesised relationships between the latent constructs. The chi-square test of the structural model $\left(\chi^{2}=1212.592 ; d f=579\right.$; $p<0.001)$ was significant, but the chi-square/df ratio $\left(\chi^{2} / d f=2.094\right)$ was under the threshold of three suggested by some authors (Hair et al., 2010; Kline, 2005). The CFI of 0.930 and RMSEA of 0.060 were also within the recommended values (Marôco, 2010). Given the sample size and the number of items, the model fit indices indicate an adequate goodness-of-fit (Hair et al., 2010). Despite the goodness-of-fit, the structural model has only supported four out of the eight proposed hypotheses (Table 6).

The latent construct local government management of tourism has both a direct and a positive effect on perceptions of the positive impacts of tourism (H4: $\beta=0.553$; $p<0.001)$, on perceptions of the negative impacts of tourism (H5: $\beta=0.198 ; p=0.003$ ) and on support to STD (H6: $\beta=0.180 ; p=0.022$ ). It is worth noting that local government management of tourism influences support to STD not only directly, but also indirectly, through perceptions of the positive impacts of tourism.

Economic dependence does not significantly influence neither on positive impacts of tourism $(\mathrm{H} 1: \beta=0.020 ; p=0.718)$, nor on negative impacts of tourism $(\mathrm{H} 2: \beta=0.084$; $p=0.187$ ) nor support to STD (H3: $\beta=-0.005 ; p=0.936$ ).

The influence of the negative impacts of tourism on support to STD was another hypothesised relationship which was not confirmed (H8: $\beta=0.063 ; p=0.307$ ). As expected, perceptions of the positive impacts of tourism has both a positive and a direct effect on support to STD (H7: $\beta=0.260 ; p=0.001$ ).

\section{Discussion and conclusions}

This study was motivated by the need for research that can lead to a better understanding of the local government's management role, the residents' economic dependence and the impacts of tourism, in fostering residents' support to STD in a historic town context. 
Table 6 Structural model's estimates

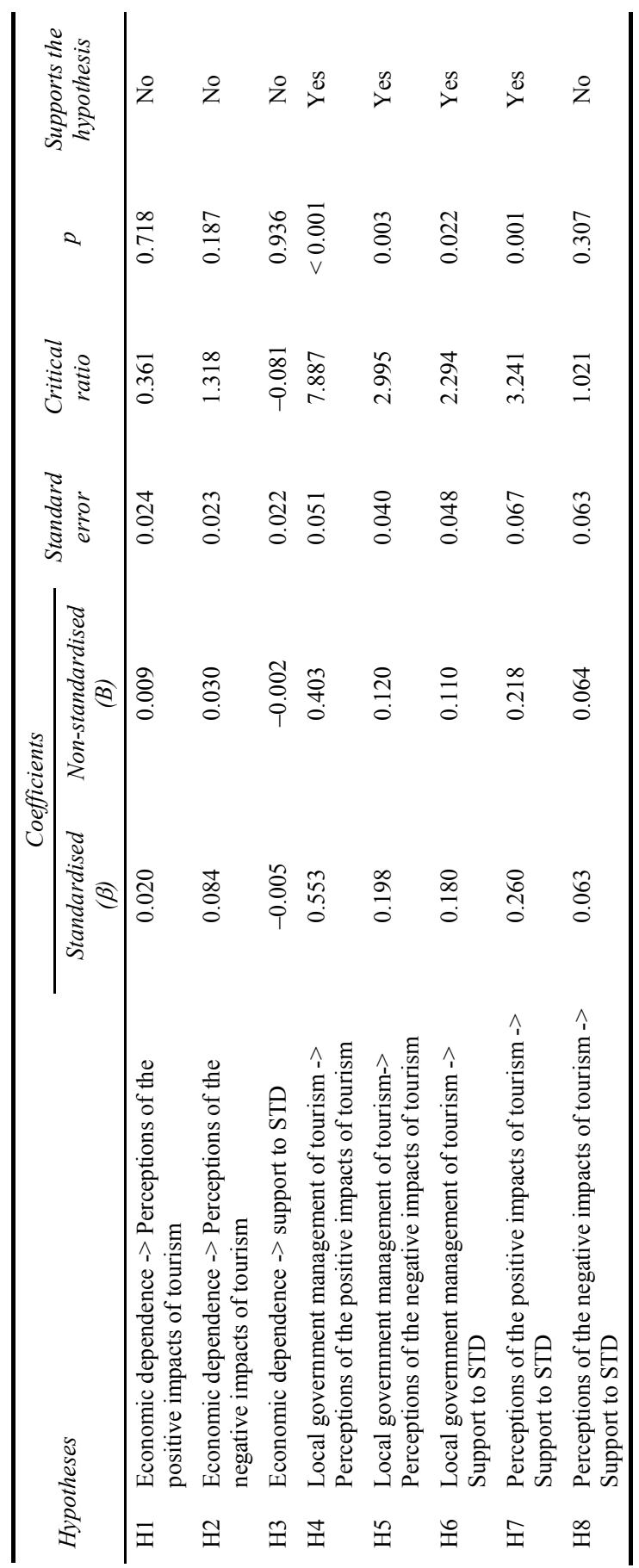


The study's results indicate that the respondents' perceptions of their economic dependence on tourism are moderate. Residents generally do not think the local government is efficiently managing tourism. Residents' support to STD is not very strong. Perceptions of the positive impacts of tourism seem to prevail among residents they recognised the economic, socio-cultural and environmental benefits of tourism and agreed to all the statements about positive impacts of tourism. Moreover, the respondents indicated disagreement with nearly all the statements regarding the negative impacts of tourism.

Regarding the proposed model, the findings supported four out of eight proposed hypotheses. Evidence was found to support the positive influence of the local government's effective management of tourism and of both positive and negative impacts of tourism. This is consistent with Assante's findings, which indicate that residents who feel the government is effective in its management of tourism development feel more positive towards the impacts of tourism. Residents tend to agree with both the positive and negative impacts of tourism when they feel the local government is an effective manager. The results indicate that if residents perceive local government management of tourism as efficient, then they are more aware of both the benefits and the costs of tourism.

Also, perceived effective local government management of tourism has both a positive and a direct effect on residents' support to STD. This result is consistent with previous studies (Assante et al., 2012a, 2012b; Lottig, 2007), suggesting that an effective local government management influences the local community's level of support to STD in a positive manner.

Perceptions of the positive impacts of tourism have both a positive and a direct effect on residents' support to STD. This result is consistent with several previous studies that also found positive relationships between the two constructs (Chen and Chen, 2010; Gursoy and Rutherford, 2004; Lee, 2013; Ling et al., 2011; Nicholas et al., 2009; Sharma and Dyer, 2009). Perceptions of the positive impacts are effective predictors of support to STD (Lee, 2013).

Four hypotheses (H1, H2, H3 and H8) were rejected, three of which concerned the economic dependence construct. Economic dependence does not have a significant influence on positive impacts of tourism. Additionally, the influence of economic dependence on negative impacts of tourism was not empirically supported. These findings contradict the conclusions of some studies that have found a positive relationship between economic dependency on tourism and perception of its impacts (Andriotis and Vaughan, 2003; García et al., 2015; Ko and Stewart, 2002; Ling et al., 2011; Perdue et al. 1990).

Notwithstanding, Chen and Chen (2010), concluded that the relationship between economic dependence and perceptions of the negative impacts of tourism; and between economic dependence and residents' support to STD was not significant. In the study of Liu and Var (1986) the results also indicated that dependence on tourism-related jobs apparently is not a significant factor. The authors explained that in their study's destination only a few residents were conscious of the industry's importance. Also, Ko and Stewart (2002) pointed out that the relationship between personal benefits from tourism development and perceptions of the negative impacts of tourism could be heavily dependent on the level of tourism development or on the residents' education level. In fact, the absence of a relationship between these constructs is consistent with Lamego's 
developmental stage, where both the negative impacts of tourism and the positive impacts of tourism go almost unnoticed by all of those involved who consequently lack perception of the advantages brought on by tourism development and STD. As García et al. (2015) points out, this result may be attributed to the particular characteristics of the destination.

Finally, perceptions of the negative impacts of tourism do not significantly contribute to residents' support to STD. Similarly, Ling et al. (2011) found that perceptions of the negative impacts of tourism are not a predictor to measure support to additional tourism development. The authors concluded that this finding was conflicting with social exchange theory. This result may also be explained by the tourist destination's stage of development, as was previously mentioned. Likewise, in accordance with the arguments presented by García et al. (2015), this small historic town's specific conditions, such as type of tourists (mainly excursionists who buy pre-organised tourism packages), the community's low economic dependence on the tourism industry and the residents' low level of knowledge about tourism, may all contribute to the nonsignificance of this association.

This study attempts to contribute to the literature on STD in small historic towns, since as it emphasises this topic within an urban context by highlighting sustainability issues related to the economic and social aspects, rather than focusing only on environmental sustainability. As we know, there are not many studies addressing these concepts within the heritage sustainability in small historic towns circumstance. In this study, we sought to propose a theoretical framework that is not commonly applied to historic towns.

We seek to add to the literature that emphasises the importance of analysing the residents' perceptions as being a major stakeholder group that should be considered in tourist planning initiatives (Cañizares et al., 2014). In this sense, and based on the stakeholder theory, the results reinforce the crucial role of local communities in decisionmaking and planning processes for STD.

One of the key objectives of this research was to attempt to contribute to the understanding of the residents' perceptions of tourism, and their support to STD. Exploring the antecedents to residents' support to STD is important because these factors can provide clues to better understand how this group's attitudes develop and can be managed.

Developing efficient tourism management is an important part of the local governments' role in tourism. Ruhanen (2013) acknowledged that some concerns have been raised about the governments' effectiveness in incorporating sustainability principles and practices within tourism's planning policies and processes. This study's model proposes that a perceived effective local government management of tourism influences the residents' perceptions of the impacts of tourism and their support to STD. We consider that these effects are also important for future theoretical developments in tourism literature. Since there have not been many studies on the role of local governments in tourism management, nor on the residents' perceptions of the impacts of tourism and their support to STD, especially in historic towns, the empirical results of this study can provide some insight into the nature of these relationships.

Considering the implications for managers, policy makers and public authorities, some practical recommendations can be made. For these and other stakeholders it is crucial to understand the predicting factors of residents' support to tourism development, mainly because the success and sustainability of any development effort put forth will 
depend on the local populations' active support (Cañizares et al., 2014; Gursoy and Rutherford, 2004). Moreover, it's important that decisions about strategies and tourism policies take the residents' concerns and opinions into account, through the definition of programs that promote the local community's participation. In doing so, as argued by Andriotis and Vaughan (2003), appropriate policies and actions that enhance the benefits and reduce the difficulties can occur. Additionally, it is also useful for an effective local government management of tourism, as was found in this study, because the local communities' perception of this management will affect their support to STD. In this manner, this information can be used to develop plans and policies to encourage residents' support to tourism and to implement STD initiatives.

In this context, local authorities and tourism managers and planners should recognise the importance of analysing the residents' perceptions in the decision-making and planning policy for tourism development. In fact, residents' adequate perception of the importance of the tourism sector can lead to a greater involvement on their part for destination management, which results in greater hospitality towards tourists. Furthermore, the destination's social, economic, cultural and environmental aspects will be more easily guaranteed.

Local governments face several challenges in efficiently planning and managing tourism. One of these challenges is related to the different perceptions and attitudes that local communities have about the implementation of STD principles. This study's findings allowed for the understanding that residents have a negative perspective on the role that has been developed by local authorities in the management of tourism. Lamego's local community considers that local government management of tourism is inefficient since their concerns have not been integrated in sustainable tourism-related plans and development. Despite the residents' low level of awareness of the negative impacts of tourism, local government should assume the responsibility of guiding local communities in the path of STD. As the results of this study point out, perceptions of effective local government management of tourism affect the perceptions of the impacts of tourism and support to STD. To achieve greater support, it is also important that Lamego's local authorities develop educational programs, for instance through internal marketing campaigns, that enhances and communicates to the local community what is their role in STD programs and initiatives.

This study had some limitations that should be addressed by future studies. The study only analysed one group - the residents - and did not examine the perceptions of other stakeholders, such as tourists, tourism officers, local economic development officers and planners, local tourism organisations, companies, and other organisations. Undoubtedly, a wider and deeper knowledge of the perceptions of other stakeholders is important for tourism planning and to define the guidelines for strategic and sustainable management of a historic destination. Also, this study was directed at the residents of only one historic town. The magnitude and direction of the studied relationships might be different if the study was conducted at other towns and regions. Additional studies should be conducted in other geographical regions.

The survey respondents were a convenience sample of Lamego's residents. As a convenience sample, residents with certain characteristics might have been underrepresented. Thus, additional studies should use other methods in order to collect more representative information. 
Another limitation is associated with the cross sectional nature of the study. Bearing in mind the growth trend of this destination, it is very likely that the community will, in the future, feel the negative impacts inherent to tourism development. In this sense, we consider it to be of crucial importance, to conduct longitudinal surveys, for the reason that the perceptions and attitudes of residents, who at this time are extremely positive towards tourism development, would most likely change throughout the evolution of the destination's lifecycle.

While the measurement of residents' economic dependence and local government management of tourism have shown reasonable validity and reliability, the use of fewer items to measure these constructs may be a limitation, and the use of a more comprehensive measurement for both constructs could also be considered in future research.

The model proposed, developed and tested in this study can be expanded in future research with the introduction of other variables and factors that may influence the residents' perceptions and attitudes, such as trust in local government and/or residents' power, which might further explain residents' support to STD.

\section{Acknowledgements}

The authors would like to thank the anonymous reviewers for their helpful and constructive comments that greatly contributed to improving the final version of this paper. They would also like to thank the Editors for their generous comments and support during the review process.

This work was supported by: European Structural and Investment Funds in the FEDER component, through the Operational Competitiveness and Internationalisation Programme (COMPETE 2020) [Project No. 006971 (UID/SOC/04011)]; and national funds, through the FCT - Portuguese Foundation for Science and Technology under the project UID/SOC/04011/2013.

\section{References}

Andereck, L., Valentine, K., Knopf, R. and Vogt, C. (2005) 'Residents' perceptions of community tourism impacts', Annals of Tourism Research, Vol. 32, No. 4, pp.1056-1076.

Andriotis, K. and Vaughan, R.D. (2003) 'Urban residents' attitudes toward tourism development: the case of Crete', Journal of Travel Research, Vol. 42, No. 2, pp.172-185.

Assante, L.M., Wen, H.I. and Lottig, K. (2012a) 'An empirical assessment of residents' attitudes for sustainable tourism development: a case study of O'ahu, Hawai'I', Journal of Sustainability and Green Business, April, Vol. 1, pp.1-27.

Assante, L.M., Wen, H.I. and Lottig, K. (2012b) 'Conceptualization of modeling resident attitudes on the environmental impacts of tourism: a case study of Oahu, Hawaii', Tourism Planning \& Development, Vol. 9, No. 2, pp.101-118.

Brida, J.G., Osti, L. and Faccioli, M. (2011) 'Residents' perception and attitudes towards tourism impacts: a case study of the small rural community of Folgaria (Trentino - Italy)', Benchmarking: An International Journal, Vol. 18, No. 3, pp.359-385.

Brokaj, R. (2014) 'Local government's role in the sustainable tourism development of a destination', European Scientific Journal, Vol. 10, No. 31, pp.103-117. 
Butler, R.W. (1980) 'The concept of tourist area cycle of evolution: implications for management of resources', Canadian Geographer, Vol. 24, No. 1, pp.5-12.

Byrd, E.T., Cardenas, D.A. and Dregalla, S.E. (2009) 'Differences in stakeholder attitudes of tourism development and the natural environment', e-Review of Tourism Research (eRTR), Vol. 7, No. 2, pp.39-51.

Cañizares, S.M.S., Tabales, J.M.N. and García, F.J.F. (2014) 'Local residents' attitudes towards the impact of tourism development in Cape Verde', Tourism \& Management Studies, Vol. 10, No. 1, pp.87-96.

CCDRN (Comissão de Coordenação e Desenvolvimento Regional do Norte) (2012) Avaliação da satisfação dos turistas da região Norte, Relatório resultados globais, Comissão de Coordenação da Região do Norte, CCDRN, Porto.

Chen, C-F. and Chen, P-C. (2010) 'Resident attitudes toward heritage tourism development', Tourism Geographies, Vol. 12, No. 4, pp.525-545.

Choay, F. (2010) A Alegoria do Património, Edições 70, Lisboa.

Deery, M., Jago, L., and Fredline, L. (2012) 'Rethinking social impacts of tourism research: a new research agenda', Tourism Management, Vol. 33, No. 1, pp.64-73.

Dyer, P., Gursoy, D., Sharma, B. and Carter, J. (2007) 'Structural modeling of resident perceptions of tourism and associated development on the Sunshine Coast, Australia', Tourism Management, Vol. 28, No. 2, pp.409-422.

Easterling, D.S. (2004) 'The residents' perspective in tourism research: a review and synthesis', Journal of Travel and Marketing, Vol. 17, No. 4, pp.45-62.

García, F.A., Vázquez, A.B. and Macías, R.C. (2015) 'Resident's attitudes towards the impacts of tourism', Tourism Management Perspectives, January, Vol. 13, pp.33-40.

Garrod, B. and Fyall, A. (2000) 'Managing heritage tourism', Annals of Tourism Research, Vol. 27, No. 3, pp.682-708.

Gorica, K., Kripa, D. and Zenelaj, E. (2012) 'The role of local government in sustainable development', Acta Universitatis Danubius.Economica, Vol. 8, No. 2, pp.139-155.

Gursoy, D. and Rutherford, D.G. (2004) 'Host attitudes toward tourism: an improved structural model', Annals of Tourism Research, Vol. 31, No. 3, pp.495-516.

Gursoy, D., Chi, C.G., and Dyer, P. (2010) 'Locals' attitudes toward mass and alternative tourism: the case of Sunshine Coast, Australia', Journal of Travel Research, Vol. 49, No. 3, pp.381-394.

Gursoy, D., Jurowski, C. and Uysal, M. (2002) 'Resident attitudes: a structural modeling approach', Annals of Tourism Research, Vol. 29, No. 1, pp.79-105.

Hair, J.F., Black, W.C., Babin, B.J. and Anderson, R.E. (2010) Multivariate Data Analysis, 7th ed., Pearson Education, Upper Saddle River, N.J., Harlow.

Haley, J., Snaith, T. and Miller, G. (2005) 'The social impacts of tourism a case study of Bath, UK', Annals of Tourism Research, Vol. 32, No. 3, pp.647-668.

Harrill, R. (2004) 'Residents' attitudes toward tourism development: a literature review with implications for tourism planning', Journal of Planning Literature, Vol. 18, No. 3, pp.251-266.

Henriques, C. (2003) Turismo Cidade e Cultura - Planeamento e Gestão Sustentável, Edições Sílabo, Lisboa [online] http://www.aabri.com/ manuscripts/10602.pdf (accessed 8 January 2014).

INE (2012) Censos 2011 resultados definitivos - Portugal, Instituto Nacional de Estatística, Lisboa.

Jackson, L. (2008) 'Residents' perceptions of the impacts of special event tourism', Journal of Place Management and Development, Vol. 1, No. 3, pp.240-255.

Jurowski, C. (1994) The Interplay of Elements Affecting Host Community Resident Attitudes Toward Tourism: A Path Analytic Approach, Unpublished PhD Thesis, Virginia Polytechnic Institute and State University, Virginia, EUA. 
Khairat, G. and Maher, A. (2012) 'Integrating sustainability into tour operator business: an innovative approach in sustainable tourism', Tourismos: An International Multidisciplinary Journal of Tourism, Vol. 7, No. 1, pp.213-233.

Kline, R.B. (2005) Principles and Practice of Structural Equation Modeling, 2nd ed., The Guilford Press, New York.

Ko, D-W. and Stewart, W.P. (2002) 'A structural equation model of residents' attitudes for tourism development', Tourism Management, Vol. 23, No. 5, pp.521-530.

Kuvan, Y. and Akan, P (2005) 'Residents' attitudes toward general and forest-related impacts of tourism: the case of Belek, Antalya', Tourism Management, Vol. 26, No. 5, pp.691-706.

Lankford, S.V. and Howard, D. (1994) 'Revising TIAS', Annals of Tourism Research, Vol. 21, No. 4, pp.829-831.

Látková, P. and Vogt, C.A. (2012) 'Residents' attitudes toward existing and future tourism development in rural communities', Journal of Travel Research, Vol. 51, No. 1, pp.50-67.

Lee, T.H. (2013) 'Influence analysis of community resident support for sustainable tourism development', Tourism Management, February, Vol. 34, pp.37-46.

Ling, L.P., Jakpar, S., Johari, A., Myint, K.T. and Rani, N.S.A. (2011) 'An evaluation on the attitudes of residents in Georgetown towards the impacts of tourism development', International Journal of Business and Social Science, Vol. 2, No. 1, pp.264-277.

Liu, J. and Var, T. (1986) 'Resident attitudes toward tourism impacts in Hawaii', Annals of Tourism Research, Vol. 13, No. 2, pp.193-214.

Lottig, K.J. (2007) Modelling Resident Attitudes on the Environmental Impacts of Tourism: A Case Study of Oahu, Hawaii, Unpublished Master's thesis, University of Hawaii.

Madrigal, R. (1995) 'Residents' perceptions and the role of government', Annals of Tourism Research, Vol. 22, No. 1, pp.86-102.

Marôco, J. (2010) Análise de Equações Estruturais - Fundamentos teóricos, software e aplicações, Editora Report Number, Pêro Pinheiro, Portugal.

Mazón, T., Huete, R. and Mantecón, A. (2009) 'Tourism dependence and host community perceptions: notes on the social exchange theory', Tourism \& Management Studies, No. 5, pp. $25-36$.

Municipality of Lamego (2013) Programa Viver Lamego - Valorização e Integração Urbana do Centro Histórico de Lamego [online] http://www.viverlamego.com/sumario-executivo/68sumario-executivo (accessed 11 March 2014).

Nicholas, L. and Thapa, B. (2010) 'Visitor perspectives on sustainable tourism development in the Pitons Management Area World Heritage Site, St. Lucia', Environment, Development and Sustainability, Vol. 12, No. 5, pp.839-857.

Nicholas, L., Thapa, B. and Ko, Y. (2009) 'Residents' perspectives of a world heritage site and the Pitons Management Area, St. Lucia', Annals of Tourism Research, Vol. 36, No. 3, pp.390-412.

Nunkoo, R. (2012) Political Economy of Tourism: Residents' Power, Trust in Government, and Political Support for Development, Unpublished Master's thesis, University of Waterloo, UK.

Nunkoo, R. and Ramkissoon, H. (2010) 'Small Island urban tourism: a residents' perspective', Current Issue in Tourism, Vol. 13, No. 1, pp.37-60.

Perdue, R.R., Long, P.T. and Allen, L. (1990) 'Resident support for tourism development', Annals of Tourism Research, Vol. 17, No. 4, pp.586-599.

Prayag, G., Hosany, S., Nunkoo, R. and Alders, T. (2013) 'London residents' support for the 2012 Olympic Games: the mediating effect of overall attitude', Tourism Management, June, Vol. 36, pp.629-640.

Pulido Fernández, J. and Sánchez Rivero, M. (2009) 'Attitudes of the cultural tourism: a latent segmentation approach applied to the case of Andalusia's middle towns initiative', in ATE2009: Proceedings of the Advances in Tourism Economics 2009 Conference, Universidade de Évora, Lisbon, Portugal, pp.23-24. 
Rodrigues, A., Vieira, I., Marques, C. and Teixeira, M. (2014) 'Apoio da comunidade residente ao desenvolvimento turístico sustentável: Um modelo de equações estruturais aplicado a uma cidade histórica do norte de Portugal', Tourism \& Management Studies, Vol. 10, No. 2, pp.1725 .

Ruhanen, L. (2013) 'Local government: facilitator or inhibitor of sustainable tourism development?', Journal of Sustainable Tourism, Vol. 21, No. 1, pp.80-98.

Ruhanen, L. and Reid, S. (2014) 'The legislative aspects of tourism policy and planning: stakeholder perspectives', International Journal of Tourism Policy, Vol. 5, No. 3, pp.192-207.

Sharma, B. and Dyer, P. (2009) 'An investigation of differences in residents' perceptions on the Sunshine Coast: tourism impacts and demographic variables', Tourism Geographies, Vol. 11, No. 2, pp.187-213.

Sharma, B. and Dyer, P. (2012) 'A longitudinal study of the residents'perceptions of tourism impacts using data from the sunshine coast Australia', Pasos Revista de Turismo y Patrimonio Cultural, Vol. 10, No. 2, pp.37-46.

Sharpley, R. (2014) 'Host perceptions of tourism: a review of the research', Tourism Management, June, Vol. 42, pp.37-49.

Stylidis, D., Biran, A., Sit, J., and Szivas, E.M. (2014) 'Residents' support for tourism development: the role of residents' place image and perceived tourism impacts', Tourism Management, December, Vol. 45, pp.260-274.

Vareiro, L. and Mendes, R. (2015) 'Residents' perspectives on tourism impacts of Portuguese World Heritage historic centers: Angra do Heroísmo and Évora', Tourism \& Management Studies, Vol. 11, No. 1, pp.44-51.

Vargas-Sánchez, A., Porras-Bueno, N. and de los Ángeles Plaza-Mejía, M. (2011) 'Explaining residents' attitudes to tourism.Is a universal model possible?', Annals of Tourism Research, Vol. 38, No. 2, pp.460-480.

Vieira, I., Rodrigues, A.P. and Teixeira, M.S. (2014) Visões e perceções de gestores do património, operadores turísticos e do poder local sobre o desenvolvimento turístico sustentável em pequenas cidades históricas: uma abordagem qualitativa, in Santos, M., Águas, P., Serra, P. and Santos, J.A.C. (Eds.): Perspetivas contemporâneas em turismo - TMS Conference series, pp.191-203, Universidade do Algarve - Escola Superior de Gestão Hoteleira e Turismo.

WTO (2005) Making Tourism More Sustainable a Guide for Policy Makers, WTO UNEP, Paris/Madrid. 